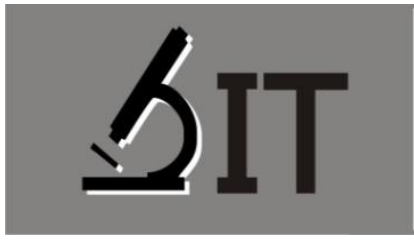

p-ISSN : 2597-8977

e-ISSN : 2597-8985

Kompyang Selamet *) Universitas Pendidikan Ganesha

Putri Sarin

Universitas Pendidikan Ganesha

I Nyoman Suardana Universitas Pendidikan Ganesha

\section{LITERASI SAINS AWAL CALON GURU PADA BIDANG IPA BERKONTEKS ISU-ISU SOSIOSAINTIFIK}

JURNAL IPA TERPADU

http://ojs.unm.ac.id/index.php/ipaterpadu

Abstrak: Penelitian ini bertujuan untuk mendeskripsikan literasi sains awal calon guru mata pelajaran IPA khususnya pada bidang IPA yang berkonteks isu-isu sosiosaintifik. Penelitian deskriptif ini melibatkan mahasiswa aktif Prodi S1 Pendidikan IPA Universitas Pendidikan Ganesha yang merupakan para calon guru. Selanjutnya dilakukan sampling dengan teknik purposive sampling hingga diperoleh 83 orang mahasiswa calon guru. Data yang dikumpulkan dalam penelitian ini adalah kemampuan literasi sains awal calon guru IPA. Instrumen yang digunakan untuk mengumpulkan data berupa tes pilihan ganda diperluas sebanyak 15 butir yang disusun mengacu pada test of scientific literacy skills. Data literasi sains awal calon guru IPA dianalisis secara deskriptif. Hasilnya adalah pada bidang IPA dengan konteks isu-isu sosiosaintifik, literasi sains awal calon guru terevaluasi dengan kualifikasi cukup. Secara individual sebanyak $6 \%$ calon guru menunjukkan kemampuan literasi sains pada kualifikasi sangat baik dan $23 \%$ baik. Sisanya calon guru menunjukkan kemampuan literasi sains dengan kualifikasi cukup (40\%), kurang (26\%) dan sangat kurang (6\%).

Kata Kunci: Literasi sains, IPA, Isu-isu Sosiosaintifik.

Abstract: This research aims to describe the initial scientific literacy of science subject teacher candidates, especially in the field of science which has a context of socio-scientific issues. This descriptive study involved 179 active students of the Ganesha Education of University Undergraduate Science Education Study Program, which was then carried out by purposive sampling technique until 83 students were obtained. The data collected in this research were the initial science literacy abilities of science teacher candidates students. The instrument used to collect data in the form of an extended multiple choice test with 12 items that were compiled according to the test of scientific literacy skills. Initial science literacy data for science teacher candidates were analyzed descriptively. The result is that in the field of science with the context of socio-scientific issues, the initial scientific literacy of prospective teachers is evaluated sufficiently. Individually, as many as $6 \%$ of teachers candidates who show scientific literacy skills at very good qualifications and $6 \%$ are good qualifications. The rest of the teachers' candidates showed sufficient scientific literacy skills (40\%), poor (26\%) and very poor (6\%).

Keyword: Scientific literacy, Science, Socio-scientific literacy 


\section{PENDAHULUAN}

Indonesia saat ini sedang berusaha untuk mengantisipasi berbagai perubahan-perubahan pada abad 21 di dunia. Ciri abad 21 ditandai dengan abad pengetahuan, abad digital globalisasi, milenium ketiga, ekonomi berbasis pengetahuan maupun pasar bebas (Redhana, 2015). Abad pengetahuan berarti masa di mana pengetahuan, teknologi dan informasi yang sangat berkembang pesat sehingga dunia seolah-olah terasa tanpa batas ( $a$ borderless world). Selain itu berbagai terobosan dan kemajuan dalam bidang sains atau ilmu pengetahuan dan teknologi juga telah membawa perubahan besar dalam meningkatkan kualitas hidup manusia di berbagai penjuru dunia (Friedman dalam Rahayu, 2015). Tidak hanya perkembangan pengetahuan saja yang pesat, tetapi saat ini muncul berbagai isu atau permasalahan-permasalahan sosial saintifik (sosiosaintifik) di berbagai tempat yang sifatnya global bahkan menyangkut etika moral seperti isu pemanasan global, kloning manusia, pertambahan penduduk, isu menipisnya sumber air tanah dan kerusakan lingkungan akibat pembangunan yang masif tidak terkendali, berkurangnya sumber energi hingga maraknya peredaran informasi-informasi tidak benar (hoax) yang meresahkan masyarakat melalui teknologi media sosial berbasis internet. Bagi para generasi muda Indonesia selaku pengguna terbesar dari teknologi internet ini, literasi sains adalah dasar yang sangat penting untuk mengantisipasi hal-hal tersebut. Melalui kemampuan literasi sains, generasi muda diharapkan dapat mampu untuk memilah dan mengkritik berbagai informasi sosial sains sehingga dapat berpartisipasi untuk ikut memberi suatu solusi atau setidaknya para generasi muda tidak menerima ataupun memproses informasi sosial sains yang salah (hoax, pseudo-sains dan lain-lain) apalagi menyebarkannya hingga mempengaruhi masyarakat sekitar.

Salah satu upaya yang telah dilakukan untuk mencapai harapan tersebut adalah adanya standar pembelajaran IPA dalam kurikulum 2013 yang menetapkan berbagai hal sebagai berikut. (1) Pembelajaran berbasis pendekatan saintifik, (2) rekomendasi model pembelajaran seperti problem based learning, discovery learning maupun project based learning, (3) kompetensi dasar (KD 3) kognitif yang berbasis high order thinking skills (HOTS) ditandai dengan kata kerja seperti menganalisis, menerapkan dan lain sebagainya, (4) kompetensi dasar (KD 3) psikomotor yang menitikberatkan pada aktivitas melakukan, melaporkan ataupun membuat suatu karya penyelidikan. Semua standar pembelajaran khususnya IPA yang telah dirancang dan dibuat sedemikian rupa oleh pemerintah seharusnya sudah sangat memadai dalam membangun atau mengembangkan kemampuan literasi sains siswa (SD, SMP, SMA) karena memang literasi sains sangat dekat dan erat dengan IPA. Hal ini dipertegas oleh Kemdikbud (2017) bahwa literasi sains terlihat jelas serta sudah mengakomodasikan pengembangan literasi sains. Apabila guru sebagai pelaksana pembelajaran mampu menjalankan standar ini dengan baik maka besar peluang peserta didik selaku generasi muda di Indonesia memiliki literasi sains yang memadai.

Kenyataan yang terjadi menunjukkan bahwa kemampuan literasi sains anak-anak Indonesia tergolong pada kriteria yang belum mencapai kata baik. Sejak kurikulum 2013 mulai dilaksanakan pada tahun 2013, beberapa penelitian untuk menggambarkan kondisi kemampuan literasi sains siswa telah menemukan beberapa hal sebagai berikut. Odja dan Payu (2014) dalam penelitiannya tentang literasi sains awal siswa di salah satu SMP Negeri Gorontalo menemukan bahwa kemampuan literasi sains awal pada siswa SMP kelas 7 hanya mencapai tingkat nominal dan fungsional dari empat tingkat keseluruhan (nominal, fungsional, konseptual/prosedural dan multidimensional). Artinya keterampilan siswa di SMP tersebut baru sebatas menuliskan atau menggunakan istilah ilmiah (nominal), menuliskan informasi dari buku teks tentang fakta-fakta dasar maupun konsep ilmiah (fungsional) dan belum mampu dalam menganalisis solusi berdasarkan penerapan konsep (konseptual/prosedural) serta belum mampu mengaitkan antar konsep dalam memecahkan permasalahan sehari-hari (multidimensional). Salamah, Rusilowati dan Sarwi (2017) dalam penelitiannya tentang pengembangan alat evaluasi materi tata surya untuk mengukur kemampuan literasi sains siswa kelas VII SMP N 41 Semarang menjelaskan bahwa ada 
empat aspek literasi sains yang diukur dengan alat evaluasi yang dikembangkan sebagai berikut: (1) Sains sebagai batang tubuh, (2) sains sebagai cara untuk menyelidiki, (3) sains sebagai cara berpikir dan (4) interaksi sains, teknologi dan masyarakat. Hasil penelitian yang diperoleh adalah siswa mencapai kategori yang baik dalam aspek sains sebagai batang tubuh, namun aspek yang lain masih cenderung pada kategori kurang.

Salah satu faktor yang paling berkontribusi terhadap pencapaian belajar suatu siswa, dengan kemampuan literasi sains salah satunya itu adalah faktor peran guru. Seperti pepatah "guru kencing berdiri maka siswa kencing berlari" yang berarti guru harus mampu menunjukkan kemampuan literasi sains seperti apa yang diharapkan untuk dikuasai oleh siswa. Kemampuan ini nantinya tidak hanya dilakukan pada situasi pembelajaran saja, namun bisa diterapkan dalam fenomena sains sosial kehidupan sehari-hari. National Research and Council (dalam Turiman, Omar, Daud dan Osman, 2012) mendefinisikan literasi sains sebagai pengetahuan dan pemahaman konsep dan proses ilmiah yang diperlukan untuk membuat suatu keputusan, berpartisipasi di dalam masyarakat dan budaya serta produktivitas ekonomi. Gormally, Brickman dan Lutz (2012) menyebutkan para pendidik sains, ilmuwan dan pengambil kebijakan setuju bahwa pengembangan literasi sains merupakan tujuan penting dalam pendidikan sains. Zeidler dan Nichol (2009) menyatakan bahwa isu-isu sosiosaintifik akan ditandai dengan adanya suatu topik ilmiah yang mengharuskan orang-orang atau siswa menjadi terlibat dalam proses dialog atau diskusi atau debat untuk membahas tentang topik ilmiah tersebut. Topik ilmiah yang dibahas sifatnya adalah kontroversial. Artinya supaya permasalahan dalam topik tersebut sampai pada keputusan yang tepat, maka diperlukan tidak hanya penalaran berbasis bukti ilmiah tetapi juga penalaran dari sisi moral atau etika. Penalaran berbasis bukti ilmiah inilah sangat memerlukan kemampuan literasi sains yang memadai sebagai dasar.

Mengingat pentingnya kemampuan literasi sains dalam fenomena atau isu-isu sosiosaintifik masyarakat, maka dipandang urgen atau perlu suatu penelitian untuk mengungkapkan kemampuan literasi sains awal, khususnya bagi para mahasiswa yang merupakan calon guru. Berkaitan dengan hal tersebut maka tujuan yang ingin dicapai dalam penelitian ini adalah mendeskripsikan literasi sains awal calon guru pada bidang IPA berkonteks isu-isu sosiosaintifik.

\section{METODE}

Penelitian ini merupakan penelitian deskriptif yang dimaksudkan untuk eksplorasi dan klarifikasi mengenai suatu fenomena atau kenyataan sosial, dengan jalan mendeskripsikan sejumlah variabel yang berkenaan dengan masalah dan unit yang diteliti (Mulyadi, 2011). Adapun variabel yang dideskripsikan adalah kemampuan literasi sains awal calon guru IPA pada pengetahuan bidang IPA yang dikaitkan dengan konteks isu-isu sosiosaintifik.

Sumber data dalam penelitian ini adalah calon guru mata pelajaran IPA yang merupakan mahasiswa aktif pada Program Studi S1 Pendidikan IPA Universitas Pendidikan Ganesha sekaligus juga sebagai populasi penelitian. Melalui teknik purposive sampling maka dari populasi 179 orang mahasiswa calon guru, ditetapkan sampel sebanyak 83 mahasiswa calon guru yang merupakan mahasiswa tahun pertama dan kedua. Penetapan sampel ini didasarkan atas pertimbangan bahwa mahasiswa ini merupakan mahasiswa aktif yang masih menempuh studi teori/praktik dalam kelas. Mahasiswa tahun ketiga juga dilibatkan dalam penelitian ini namun partisipasinya dibutuhkan sebagai responden untuk uji lapangan instrumen penelitian. Mahasiswa tahun keempat tidak dilibatkan dalam penelitian karena sedang dalam proses pengembangan pengalaman lapangan dan mereka sedang tersebar di berbagai sekolah mitra sehingga sulit diambil datanya.

Data literasi sains awal dikumpulkan dengan menggunakan instrumen TOSLS atau test of scientific literacy skills (Gormally et al., 2012) berbentuk tes pilihan ganda dengan alasan (tes pilihan ganda diperluas) sebanyak 15 butir. Tiap-tiap butir tes mewakili sebanyak sembilan indikator kemampuan literasi sains. Sebanyak empat indikator merupakan aspek kemampuan memahami 
berbagai metode-metode penyelidikan yang mengarah pada pengetahuan ilmiah. Sebanyak lima indikator sisanya merupakan aspek mengorganisasi, menganalisis dan menginterpretasi data kuantitatif serta informasi ilmiah.

Sebelum masuk tahap pengambilan data, instrumen penelitian telah melalui proses uji validitas meliputi uji validitas isi, uji validitas konstruk dan uji coba lapangan. Pada aspek isi serta konstruk instrumen ini dinyatakan valid setelah melalui revisi yang didasarkan atas hasil diskusi konsultasi bersama dua orang dosen pendidikan IPA Undiksha. Selanjutnya dari hasil uji coba lapangan yang mengukur konsistensi internal butir tes dan reliabilitas tes memeroleh hasil sebagai berikut. (1) Sebanyak 15 butir tes yang dianalisis dengan persamaan product moment mendapatkan nilai koefisien korelasi tertinggi sebesar 0,597 dan terendah sebesar 0,354. Koefisien ini lebih tinggi dari nilai $r$ tabel ( $d k=43-1, a=0,05$ diperoleh $r$ tabel 0,304) sehingga secara kaidah statistika, semua butir tes dinyatakan konsisten. Selanjutnya hasil analisis perhitungan reliabilitas tes dengan metode Alpha Cronbach berbantuan program SPSS 22 memperoleh nilai sebesar 0,721. Nilai ini tergolong tinggi dan instrumen dapat dinyatakan reliabel. Keseluruhan proses validasi instrumen ini menunjukkan bahwa instrumen tes dalam penelitian ini telah layak digunakan untuk pengambilan data.

Data yang telah dikumpulkan selanjutnya dianalisis dengan teknik deskriptif. Teknik ini mengolah data penelitian agar dapat menyajikan profil literasi sains awal mahasiswa calon guru baik dilihat dari keseluruhan secara umum, dilihat berdasarkan pengelompokkan semester atau tahun angkatan serta dilihat per indikator literasi sains. Untuk menyatakan kualifikasi literasi sains awal calon guru, maka diawali dengan teknik penskoran di mana tiap satu butir tes pilihan ganda dengan alasan memiliki skor minimum nol dan skor maksimum empat. Skor empat pada butir diberikan apabila jawaban mahasiswa calon guru berupa pilihan opsi tepat dan disertai dengan alasan yang tepat mengikuti indikator kerja literasi sains pada instrumen. Skor tiga diberikan apabila opsi jawaban yang dipilih tepat, namun substansi alasan kurang lengkap walaupun secara umum alasan tersebut tepat. Skor dua diberikan apabila opsi jawaban yang dipilih tepat namun tanpa alasan atau alasan salah. Opsi jawaban salah dengan atau tanpa disertai alasan mendapatkan skor satu. Apabila sama sekali tidak menjawab, maka diberikan skor nol.

Total skor maksimum tes sebanyak 15 butir yaitu 60 dan skor minimum nol. Melalui perhitungan skala lima maka ditetapkan kualifikasi sebagai berikut.

Tabel 1. Kualifikasi Kemampuan Literasi Sains Awal Calon Guru

\begin{tabular}{ccc}
\hline Perhitungan Skala Lima & Rentang skor & Kualifikasi \\
\hline$X \geq M_{i}+1,5 S D_{i}$ & $X \geq 45$ & Sangat Baik \\
$M_{i}+0,5 S D_{i} \leq X<M_{i}+1,5 S D_{i}$ & $35 \leq X<45$ & Baik \\
$M_{i}-0,5 S D_{i} \leq X<M_{i}+0,5 S D_{i}$ & $25 \leq X<35$ & Cukup \\
$M_{i}-1,5 S D_{i} \leq X<M_{i}-0,5 S D_{i}$ & $15 \leq X<25$ & Kurang \\
$X<M_{i}-1,5 S D_{i}$ & $X<15$ & Sangat Kurang \\
\hline
\end{tabular}

Keterangan

$\mathrm{X}$ : Skor tes literasi sains yang diperoleh mahasiswa (maksimum 60 minimum 0 )

Mi : Mean ideal (jumlah skor maksimum dengan skor minimum dibagi dua)

Sd : Standar deviasi ideal (jumlah skor maksimum dengan skor minimum dibagi enam

Kualifikasi literasi sains awal calon guru juga dilihat dari tiap indikator. Mengingat skor maksimum tiap butir adalah empat dan skor minimumnya adalah nol maka dengan menggunakan perhitungan skala lima ditetapkan sebagai berikut. 
Tabel 2. Kualifikasi Kemampuan Literasi Sains Awal Calon Guru Berdasarkan Tiap Indikator Kemampuan Literasi Sains Awal

\begin{tabular}{ccc}
\hline Perhitungan Skala Lima & Rentang skor & Kualifikasi \\
\hline$X \geq M_{i}+1,5 S D_{i}$ & $X \geq 3,00$ & Sangat Baik \\
$M_{i}+0,5 S D_{i} \leq X<M_{i}+1,5 S D_{i}$ & $2,33 \leq X<3,00$ & Baik \\
$M_{i}-0,5 S D_{i} \leq X<M_{i}+0,5 S D_{i}$ & $1,67 \leq X<2,33$ & Cukup \\
$M_{i}-1,5 S D_{i} \leq X<M_{i}-0,5 S D_{i}$ & $1 \leq X<1,67$ & Kurang \\
$X<M_{i}-1,5 S D_{i}$ & $X<1$ & Sangat Kurang \\
\hline
\end{tabular}

Keterangan

$X \quad$ : Skor rerata tes literasi sains yang diperoleh mahasiswa tiap butir tes atau tiap indikator tes (maksimum 4 minimum o)

$M_{i} \quad$ : Mean ideal (jumlah skor maksimum dengan skor minimum dibagi dua)

Sd : Standar deviasi ideal (mean ideal dibagi tiga)

\section{HASIL DAN PEMBAHASAN}

1. Hasil

\section{a. Profil Literasi Sains Awal Calon Guru Secara Umum}

Jumlah seluruh mahasiswa calon guru yang berhasil diambil datanya pada penelitian ini adalah sebanyak 83 orang baik dari mahasiswa tahun pertama (semester I) maupun mahasiswa tahun kedua (semester III). Jumlah ini sudah total akhir setelah dikurangi beberapa orang yang tidak dapat diambil datanya karena tidak hadir dengan alasan sakit dan izin serta beberapa orang telah pindah program studi begitu proses pengambilan data dilakukan. Profil literasi sains awal mahasiswa calon guru secara umum disajikan pada Tabel 3 .

Tabel 3. Skor Rerata Literasi Sains Awal Seluruh Mahasiswa Calon Guru

\begin{tabular}{clcc}
\hline No & Mahasiswa Calon Guru & Rerata Skor & Simpangan baku \\
\hline 1 & Tahun kedua (Semester III) & 35,30 & 6,86 \\
2 & Tahun pertama (Semester I) & 23,36 & 6,85 \\
& Rerata mahasiswa keseluruhan & \multicolumn{2}{c}{30,12} \\
& Simpangan baku mahasiswa keseluruhan & \multicolumn{2}{c}{9,05} \\
\hline
\end{tabular}

Berdasarkan rerata mahasiswa calon guru keseluruhan sebesar 30,12 maka literasi sains awal mahasiswa calon guru tergolong pada kualifikasi cukup. Apabila dikelompokkan berdasarkan tahun studi, diperoleh bahwa literasi sains awal mahasiswa calon guru tahun pertama lebih rendah dibandingkan mahasiswa calon guru tahun kedua (bahkan berkualifikasi kurang). Adapun sebaran jumlah mahasiswa calon guru yang menunjukkan kualifikasi literasi sains awal dari sangat baik hingga sangat kurang, disajikan pada gambar 1. 


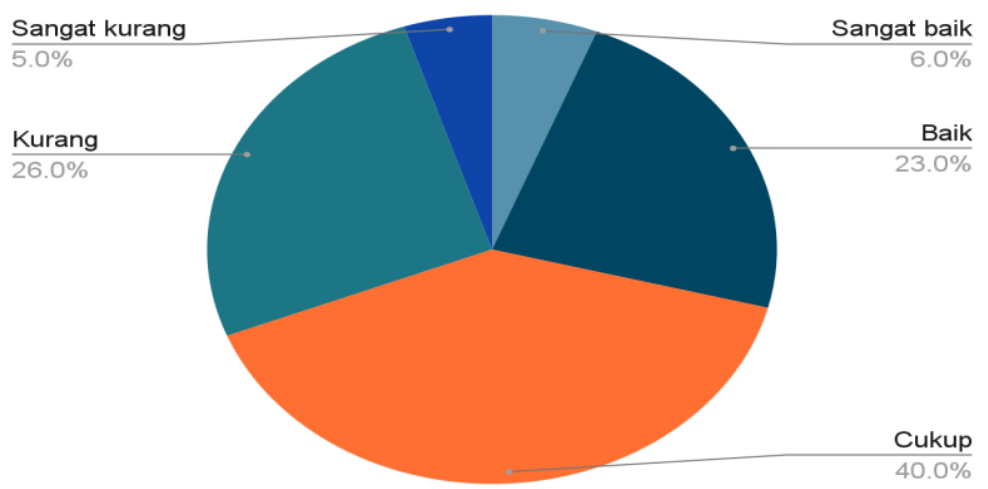

\section{Gambar 1. Sebaran Persentase Jumlah Mahasiswa Calon Guru Berdasarkan Kualifikasi Kemampuan Literasi Sains Awal Yang Ditunjukan.}

Gambar 1 menunjukkan bahwa tidak lebih dari setengah total mahasiswa calon guru yang menunjukkan literasi sains awal dengan kualifikasi yang diharapkan (29\% terdiri dari $23 \%$ baik dan $6 \%$ sangat baik). Paling banyak kemampuan literasi sains awal mahasiswa calon guru berada pada kualifikasi cukup (40\%) dan sisanya adalah calon guru dengan kemampuan literasi sains yang kurang (26\%) serta sangat kurang (5\%).

\section{b. Profil Literasi Sains Awal Calon Guru berdasarkan Indikator Kemampuan dan Konteks Isu-Isu Sosiosaintifik}

Literasi sains menurut Gormally et al. (2012) terdiri dari dua aspek kemampuan meliputi (1) memahami berbagai metode-metode penyelidikan yang mengarah pada pengetahuan ilmiah dan (2) mengorganisasi, menganalisis dan menginterpretasi data kuantitatif serta informasi ilmiah. Masing-masing aspek kemampuan ini terdiri dari beberapa indikator kemampuan yang lebih spesifik dengan total sebanyak sembilan indikator. Profil literasi sains awal calon guru dilihat dari tiap-tiap indikator literasi sains dapat disajikan pada Tabel 4 .

Tabel 4. Skor rerata literasi sains awal seluruh mahasiswa calon guru dilihat per indikator dan materi maupun konteks isu-isu sosiosaintifik yang termuat

\begin{tabular}{|c|c|c|c|c|}
\hline $\begin{array}{c}\text { Aspek Kemampuan } \\
\text { Literasi Sains }\end{array}$ & $\begin{array}{l}\text { Indikator Literasi } \\
\text { Sains dan Kode }\end{array}$ & Materi/Isu-isu sosiosaintifik & $\begin{array}{c}\text { Rerata } \\
\text { Skor }\end{array}$ & Kualifikasi \\
\hline \multirow[t]{2}{*}{$\begin{array}{l}\text { Memahami berbagai } \\
\text { metode-metode } \\
\text { penyelidikan yang } \\
\text { mengarah pada } \\
\text { pengetahuan ilmiah }\end{array}$} & $\begin{array}{l}\text { Mengidentifikasi } \\
\text { argumen ilmiah yang } \\
\text { tepat (Kode LS 1) }\end{array}$ & $\begin{array}{l}\text { 1. Biosfer/Isu berbagai } \\
\text { penyebab terjadinya } \\
\text { fenomena cuaca di Bali } \\
\text { 2. Keanekaragaman } \\
\text { makhluk hidup/Isu perlu } \\
\text { tidaknya eliminasi anjing } \\
\text { liar di Bali }\end{array}$ & 2,07 & Cukup \\
\hline & $\begin{array}{l}\text { Mengevaluasi } \\
\text { ketepatan dan } \\
\text { keabsahan sumber } \\
\text { informasi (Kode LS 2) }\end{array}$ & $\begin{array}{l}\text { 1. Mitigasi bencana } \\
\text { alam/Isu bencana gempa } \\
\text { bumi } \\
\text { 2. Hidrosfer/Isu tentang } \\
\text { pariwisata dan dampak } \\
\text { alam yang ditimbulkan }\end{array}$ & 2,56 & Baik \\
\hline
\end{tabular}




\begin{tabular}{|c|c|c|c|c|}
\hline $\begin{array}{l}\text { Aspek Kemampuan } \\
\text { Literasi Sains }\end{array}$ & $\begin{array}{l}\text { Indikator Literasi } \\
\text { Sains dan Kode }\end{array}$ & Materi/Isu-isu sosiosaintifik & $\begin{array}{l}\text { Rerata } \\
\text { Skor }\end{array}$ & Kualifikasi \\
\hline & & $\begin{array}{l}\text { khususnya air tanah di } \\
\text { Bali }\end{array}$ & & \\
\hline & $\begin{array}{l}\text { Mengevaluasi } \\
\text { kebergunaan } \\
\text { informasi-informasi } \\
\text { ilmiah (Kode LS 3) }\end{array}$ & $\begin{array}{l}\text { 1. Kesehatan/Isu terkait pro } \\
\text { dan kontra pemberian } \\
\text { vaksin Measles Rubella di } \\
\text { masyarakat }\end{array}$ & 2,22 & Cukup \\
\hline & $\begin{array}{l}\text { Mendeskripsikan } \\
\text { komponen desain } \\
\text { penelitian serta } \\
\text { dampaknya terhadap } \\
\text { temuan atau } \\
\text { simpulan ilmiah } \\
\text { (Kode LS 4) }\end{array}$ & $\begin{array}{l}\text { 1. Metode ilmiah/Isu yang } \\
\text { berkaitan dengan } \\
\text { aktivitas-aktivitas } \\
\text { masyarakat } \\
\text { 2. Pertanian/Isu efek } \\
\text { penggunaan pestisida } \\
\text { pada tanaman }\end{array}$ & 2,09 & Cukup \\
\hline \multirow[t]{5}{*}{$\begin{array}{l}\text { Mengorganisasi, } \\
\text { menganalisis dan } \\
\text { menginterpretasi } \\
\text { data kuantitatif serta } \\
\text { informasi ilmiah }\end{array}$} & $\begin{array}{l}\text { Menggambar } \\
\text { diagram atau grafik } \\
\text { atau bagan sesuai } \\
\text { dengan data (Kode } \\
\text { LS 5) }\end{array}$ & $\begin{array}{l}\text { 1. Kesehatan/Isu seks pra- } \\
\text { nikah pada remaja } \\
\text { 2. Hidrosfer/Isu } \\
\text { menurunnya persediaan } \\
\text { air tanah di masa depan }\end{array}$ & 1,77 & Cukup \\
\hline & $\begin{array}{l}\text { Membaca dan } \\
\text { menginterpretasikan } \\
\text { diagram atau grafik } \\
\text { atau bagan (Kode LS } \\
\text { 6) }\end{array}$ & $\begin{array}{l}\text { 1. Pencemaran udara/Isu } \\
\text { meningkatnya kadar } \mathrm{CO}_{2} \\
\text { di udara } \\
\text { 2. Pencemaran air/lsu } \\
\text { ancaman kepunahan } \\
\text { hewan endemik karena } \\
\text { pencemaran air }\end{array}$ & 1,90 & Cukup \\
\hline & $\begin{array}{l}\text { Memecahkan } \\
\text { masalah dengan } \\
\text { menggunakan } \\
\text { keterampilan } \\
\text { kuantitatif termasuk } \\
\text { penggunaan peluang } \\
\text { dan statistik (Kode } \\
\text { LS 7) }\end{array}$ & $\begin{array}{l}\text { 1. Kesehatan/Isu } \\
\text { penggunaan vaksin pada } \\
\text { hewan }\end{array}$ & 2,28 & Cukup \\
\hline & $\begin{array}{l}\text { Menginterpretasikan } \\
\text { data dengan } \\
\text { mengacu pada } \\
\text { statistik dasar (Kode } \\
\text { LS 8) }\end{array}$ & $\begin{array}{l}\text { 1. Pangan dan Metode } \\
\text { ilmiah/Isu tentang } \\
\text { konsumsi minuman keras } \\
\text { di Bali (arak) }\end{array}$ & 1,49 & Kurang \\
\hline & $\begin{array}{l}\text { Menjustifikasi } \\
\text { kesimpulan, prediksi } \\
\text { dan kesimpulan } \\
\text { berdasarkan data } \\
\text { kuantitatif (Kode LS } \\
\text { 9) }\end{array}$ & $\begin{array}{l}\text { 1. Kesehatan dan Metode } \\
\text { Ilmiah/Isu tentang } \\
\text { autisme pada anak } \\
\text { 2. Metode ilmiah/Isu } \\
\text { penerapan riset ilmiah } \\
\text { dalam kehidupan sehari- } \\
\text { hari }\end{array}$ & 1,87 & Cukup \\
\hline
\end{tabular}


Tabel 4 menunjukkan bahwa kemampuan terbaik mahasiswa calon guru ada pada kode indikator LS 2 yaitu mengevaluasi ketepatan dan keabsahan sumber informasi. Ditinjau pada instrumen tes, sebagian besar mahasiswa calon guru dapat menentukan tepat atau tidaknya, absah atau tidaknya suatu sumber informasi dengan mengajukan alasan berupa konsepkonsep IPA ilmiah, khususnya pada peristiwa bencana alam gempa bumi dan isu tentang kondisi air tanah di Bali. Selanjutnya kemampuan yang terlihat paling rendah adalah pada kode indikator LS 8 yaitu menginterpretasikan data dengan mengacu pada statistik dasar. Pada tes disajikan tentang data persentase kandungan alkohol pada dua kelompok minuman arak Bali. Konsep ilmiah yang digunakan sesungguhnya adalah tentang rata-rata/mean dan simpangan baku untuk menginterpretasi kepastian kadar alkohol dalam minuman keras, namun kebanyakan mahasiswa calon guru tidak teliti dalam mencermati teks, sehingga memilih serta mengajukan alasan jawaban yang salah. Walaupun demikian hampir seluruh indikator kemampuan literasi sains mahasiswa calon guru masih dibawah kualifikasi baik, atau tergolong kualifikasi cukup. Artinya sebagian mahasiswa calon guru menunjukkan kemampuan literasi yang baik dalam memberikan penjelasan tiap pilihan jawaban tes, namun tidak sedikit pula mahasiswa calon guru yang kurang memadai dalam menjelaskan tiap pilihan jawaban tes. Pelibatan konsep ilmiah dan statistika dalam menjelaskan suatu alasan jawaban dinilai masih kurang.

\section{Pembahasan}

Secara umum, literasi sains awal calon guru pada bidang materi IPA berkonteks isu-isu sosiosaintifik terevaluasi cukup. Hanya $29 \%$ saja yang menunjukkan kemampuan literasi sains awal di atas kriteria cukup. Jika dicermati berdasarkan kelompok angkatan, maka rerata skor literasi sains awal mahasiswa tahun kedua secara deskriptif lebih tinggi dibandingkan rerata skor literasi sains awal mahasiswa tahun pertama. Kondisi ini dimungkinkan terjadi akibat faktor perbedaan pengalaman kuliah di mana mahasiswa tahun kedua telah menempuh lebih banyak mata kuliah keIPA-an (fisika dasar, biologi dasar, IPA dasar dan ilmu kebumian) ditambah dengan statistika, sementara kelompok mahasiswa tahun pertama belum mengambil dan mengikuti mata kuliah ilmu kebumian maupun statistika. Dalam instrumen tes literasi sains yang mengacu pada indikator TOSLS (test of scientific literacy skills), hampir sebagian indikator kemampuan literasi sains merupakan ranah statistika seperti penyusunan data dalam grafik, peluang statistik, interpretasi data dengan statistik dan lain sebagainya. Apabila mengacu pada pernyataan Norris dan Phillips (dalam Christenson, 2015) bahwa literasi sains mencakup sejumlah komponen meliputi pengetahuan tentang alam, konsep-konsep dan teori-teori ilmiah. Melihat konsep literasi sains tersebut, seharusnya mahasiswa calon guru dari dua angkatan ini memilikinya. Produk IPA berupa pengetahuan, konsep, teori dan lain sebagainya telah mereka dapatkan pada saat di bangku sekolah (SMP maupun SMA terutama pada mata pelajaran IPA maupun matematika) dan ini bisa diterapkan sebagai kemampuan untuk merespon isu-isu sosiosaintifik pada instrumen tes yang mereka kerjakan. Kemungkinan terbesarnya perbedaan hasil literasi sains pada penelitian ini adalah tidak semua konten materi di bangku sekolah tersebut benar-benar dipahami dengan baik serta hanya masuk pada memori jangka pendek mahasiswa calon guru.

Literasi sains awal mahasiswa calon guru pada penelitian ini menunjukkan kondisi yang tidak jauh berbeda dengan penelitian sebelumnya. Shofiyah (2015) dalam penelitiannya tentang deskripsi literasi sains awal pada mahasiswa pendidikan IPA Universitas Muhammadiyah Sidoarjo menemukan bahwa dari empat tingkatan kemampuan pada literasi sains, sebagian besar mahasiswa menunjukkan kemampuan yang baik pada dua tingkatan terdasar yaitu kemampuan nomina dan fungsional. Kemampuan ini disebut sebagai kemampuan menggunakan istilah-istilah ilmiah untuk menjelaskan berbagai fenomena alam. Sementara dua tingkat kemampuan literasi sains berikutnya yaitu konseptual/prosedural beserta multidimensional masih minim mahasiswa 
menunjukkan kemampuan ini. Kemampuan konseptual/prosedural mencakup kemampuan mahasiswa dalam inkuiri dan metode-metode ilmiah serta kemampuan multidimensional mencakup kemampuan untuk mengaitkan antara sains, sosial dan teknologi. Kondisi ini hampir sama dengan hasil penelitian ini di mana sebagian besar aspek kemampuan mengorganisasi, menganalisis dan menginterpretasi data kuantitatif serta informasi ilmiah tergolong kriteria cukup bahkan kurang.

Temuan penelitian berikutnya adalah literasi sains awal mahasiswa calon guru dilihat dari tiap indikator kemampuan sekaligus konteks isu-isu sosiosaintifik yang dikaitkan. Isu-isu sosiosaintifik sebagai konteks dalam materi IPA pada dasarnya adalah memuat fenomena sains-sosial pada konten IPA dan fenomena ini bersifat kontroversial dan terbuka. Salder dan Zeidler (dalam Herlanti, Rustaman, Rohman \& Fitriani, 2012) menjelaskan bahwa Isu-isu sosiosaintifik adalah isu-isu yang berdasarkan tentang konsep atau masalah ilmiah, yang bersifat kontroversial, dibahas di tempat umum dan sering kali menjadi subjek pengaruh politik dan sosial. Perlu suatu pemikiran kritis-ilmiah untuk mengambil suatu jawaban atau keputusan atas masalah ilmiah tersebut. Sebagai contoh ada pada materi keanekaragaman makhluk hidup dengan isu adanya wacana untuk eliminasi anjinganjing di Bali yang tidak memiliki majikan. Ada dua sisi yang harus dipilih pada wacana eliminasi anjing tersebut. Di satu sisi, banyaknya anjing liar dikhawatirkan akan menyebabkan penyebaran penyakit rabies serta perilaku anjing liar itu sendiri yang sering membuat lingkungan kotor karena mengais sampah. Sisi lainnya adalah anjing-anjing asli Bali ini akan menjadi terancam punah jika dieliminasi mengingat banyaknya jenis anjing persilangan atau anjing ras luar Bali yang dipelihara dengan baik. Bagi mahasiswa calon guru, fenomena yang bersifat dilema ini menjadi sarana untuk menyampaikan jawaban atau solusi dengan mengacu pada konsep maupun teori ilmiah (indikator literasi sainsnya adalah mengidentifikasi argumentasi ilmiah). Adapun isu sosiosaintifik yang mampu direspon dengan baik oleh sebagian besar mahasiswa calon guru ada pada materi tentang mitigasi bencana serta hidrosfer. Isu sosiosaintifik yang dikaitkan sebagai konteks adalah tentang prediksi terjadinya gempa bumi dan dampak pariwisata khususnya pada ketersediaan air tanah di Bali. Melalui indikator kemampuan literasi sains berupa kemampuan mengevaluasi ketepatan dan keabsahan sumber informasi, sebagian besar mahasiswa calon guru mampu memberi suatu penilaian serta mengevaluasi apakah informasi yang dibaca pada artikel (pada naskah tes) tersebut benar atau tidak. Berdasarkan butir tes yang memuat unggahan tulisan media sosial tentang pesan bahwa akan terjadi gempa bumi, sebagian besar mahasiswa calon guru dapat menjelaskan bahwa informasi tersebut tidak tepat atau tidak absah. Penjelasan ini didasarkan pada teori serta konsep tentang gempa bumi yang kemunculannya tidak dapat diprediksikan sepenuhnya baik lokasi maupun waktu terjadinya. Selanjutnya ada butir tes yang memuat artikel surat kabar yang mengulas bahwa beberapa puluh tahun ke depan, Bali akan kekurangan cadangan air tanah. Sebagian besar mahasiswa menyimpulkan artikel tersebut merupakan informasi yang tepat dan absah serta menunjukkan konsep atau teori tentang hidrosfer yang mendukung pernyataan artikel tersebut.

Adapun kemampuan literasi sains yang tergolong paling rendah adalah kemampuan menginterpretasi data dengan mengacu pada statistik dasar. Sebagian besar mahasiswa keliru dalam memilih jawaban ataupun kurang tepat dalam menjelaskan terkait dengan isu kepastian kandungan alkohol pada arak, minuman keras khas Bali. Konsep statistik dasar yang seharusnya diterapkan untuk menginterpretasi kepastian kandungan alkohol pada tiap-tiap botol arak yaitu hanya menggunakan konsep rata-rata atau mean, serta simpangan baku atau standar deviasi. Jadi kelompok botol arak dengan rata-rata alkohol sebesar sekian persen dan nilai simpangan bakunya besar, kecenderungan kepastiannya lebih rendah dibandingkan kelompok arak dengan nilai simpangan baku yang lebih kecil. Hal ini yang tidak banyak dapat dijawab benar oleh mahasiswa, khususnya sebagian besar mahasiswa tahun pertama.

Berdasarkan semua indikator keseluruhan pada tes dengan mengacu pada tabel 5 , sebagian besar kemampuan mahasiswa calon guru berkriteria cukup. Artinya ketika menjawab tes literasi 
sains dengan materi IPA yang berkonteks isu-isu sosiosaintifik, sebagian mahasiswa dapat memilih jawaban yang tepat disertai dengan alasan yang tepat, namun sebagian mahasiswa memilih jawaban yang salah atau memilih jawaban yang tepat namun alasan kurang memadai. Salah satu contoh jawaban dengan alasan kurang memadai yaitu pada tes tentang prediksi kepunahan pada hewan pesut (disebut juga lumba-lumba air tawar) yang hidup di sungai-sungai Kalimantan. Telah disajikan tabel data-data parameter kondisi air pada salah satu sungai yang ada di Kalimantan baik dari parameter biologi, kimia dan fisika. Mahasiswa diminta untuk menganalisis tabel data tersebut dan memberikan interpretasi dengan memilih jawaban serta dilengkapi alasan yang tepat. Alasan yang diberi oleh mahasiswa, tidak mengacu pada proses pembacaan atau analisis tabel data yang disajikan, melainkan malah menggunakan pendapat pribadi untuk merespon butir tes tentang pesut tersebut. Kondisi ini ternyata memiliki kesamaan dengan hasil penelitian sebelumnya, di mana Novitasari (2018) dalam penelitiannya tentang profil kemampuan literasi sains mahasiswa calon guru biologi di Universitas Muhammadiyah Palembang menggunakan aspek atau indikator kemampuan literasi sains yang serupa dengan instrumen yang digunakan dalam penelitian ini. Hasilnya adalah kemampuan memahami dan menginterpretasi statistik dasar menjadi kemampuan yang paling rendah dibandingkan kemampuan lainnya. Kemungkinan besar faktor pengetahuan siswa tentang statistika dasar yang memberikan kontribusi signifikan di mana pengetahuan statistika dasar yang sesungguhnya diberikan di mata pelajaran matematika SMA kurang terserap dengan baik. Satu-satunya yang dapat menolong adalah pengetahuan yang diperoleh dari mata kuliah statistika dasar ataupun statistika pendidikan. Selain itu, hal yang cukup menarik adalah perbedaan kemampuan mengevaluasi ketepatan dan keabsahan sumber informasi. Pada penelitian ini, kemampuan mahasiswa calon guru terevaluasi dengan kriteria baik, namun pada penelitian sebelumnya oleh Novitasari (2018) disebutkan bahwa kemampuan yang serupa (penelusuran literatur yang efektif) tergolong rendah. Kemungkinannya adalah mahasiswa calon guru pada penelitian ini menjawab butir tes dengan konten materi IPA yang baru saja dipelajari selama mengikuti perkuliahan, sehingga butir tes tersebut dapat dijawab dengan baik.

Berdasarkan data kemampuan literasi sains awal yang sudah diperoleh dalam penelitian ini, implikasinya adalah mahasiswa yang dengan kemampuan literasi sains yang cukup maupun kurang, harus ditingkatkan kembali kemampuannya sebelum nanti lulus menjadi guru. Sementara mahasiswa calon guru yang telah menunjukkan kemampuan literasi sains awal yang baik juga harus tetap mempertahankan dan meningkatkan kemampuannya untuk nanti diterapkan saat mereka telah bekerja sebagai seorang guru. Adapun upaya untuk bisa mewujudkan hal ini adalah kontribusi dari pihak dosen pengajar dalam melaksanakan perkuliahan yang dapat mengasah kemampuan literasi sains mahasiswa calon guru, serta yang terpenting tentu inisiatif dan keaktifan mahasiswa calon guru itu sendiri di dalam meningkatkan kapabilitas keilmuannya selama mengikuti perkuliahan.

Penelitian ini telah dapat memberikan gambaran terkait dengan kemampuan literasi sains awal mahasiswa calon guru, khususnya pada materi IPA yang berkonteks isu-isu sosiosaintifik. Namun terdapat sejumlah keterbatasan-keterbatasan yang memaksa penelitian ini dilaksanakan dalam kondisi yang tidak sepenuhnya sesuai rencana. Keterbatasan pertama yaitu terkait responden penelitian yang tidak dapat melibatkan mahasiswa tahun ketiga maupun keempat. Padahal sesuatu yang sangat menarik untuk mengungkap kemampuan literasi sains awal mahasiswa tahun keempat mengingat mahasiswa ini akan menjelang lulus sarjana dan berpeluang untuk segera menjadi guru. Hal yang terjadi adalah mahasiswa tahun keempat sedang dalam masa pengembangan pengalaman lapangan atau pengenalan lapangan persekolahan lanjut. Mahasiswa sedang berada di sekolah untuk latihan sekaligus praktik mengajar sehingga proses pengambilan data dengan pemberian tes menjadi tidak dapat dilaksanakan. Sementara mahasiswa tahun ketiga menjadi responden yang harus digunakan oleh peneliti untuk melakukan proses pengujian instrumen tes literasi sains yang digunakan untuk mengambil data. Keterbatasan kedua yaitu instrumen tes literasi sains dengan isu-isu sosiosaintifik. Tidak mudah memang menyusun butir tes 
yang memuat konteks atau fenomena yang benar-benar bersifat sosiosaintifik, mengingat harus memperhatikan aspek indikator literasi sains serta berkaitan dengan materi ke-IPA-an. Selain itu pula hanya kemampuan literasi sains saja yang difokuskan pada materi IPA yang dimuatkan konteks isu-isu sosiosaintifik, sementara isu-isu sosiosaintifik ini juga sangat baik diteliti kaitannya dengan kemampuan berpikir tingkat tinggi seperti berpikir kritis, kemampuan argumentasi dan lain sebagainya.

\section{KESIMPULAN}

Kesimpulan yang diperoleh dari penelitian ini yaitu kemampuan literasi sains awal khususnya pada materi IPA yang berkonteks isu-isu sosiosaintifik terevaluasi pada kriteria cukup. Secara individual sebanyak $6 \%$ calon guru menunjukkan kemampuan literasi sains pada kualifikasi sangat baik dan $23 \%$ baik. Sisanya calon guru menunjukkan kemampuan literasi sains dengan kualifikasi cukup (40\%), kurang (26\%) dan sangat kurang (6\%). Berdasarkan simpulan penelitian ini peneliti memiliki beberapa rekomendasi yang dapat dijadikan sebagai bahan pertimbangan bagi berbagai pihak. (1) Mahasiswa calon guru mata pelajaran IPA wajib untuk meningkatkan kemampuan literasi sains untuk nanti dibelajarkan pada peserta didik. (2) Dosen pengajar mata kuliah yang relevan (mata kuliah ke-IPA-an) sangat disarankan untuk memfasilitasi proses perkuliahan mahasiswa agar mahasiswa dapat mengembangkan salah satu kemampuan pentingnya yaitu literasi sains. (3) Disarankan bagi peneliti lain yang mengambil topik penelitian yang serupa untuk memperluas atau memperbanyak jumlah subjek penelitiannya pada mahasiswa untuk mendapatkan gambaran kemampuan literasi sains mahasiswa calon guru yang lebih komprehensif.

\section{DAFTAR PUSTAKA}

Christenson, N. (2015). Socioscientific argumentation. (Dissertation). Karlstad University Studies. Tersedia pada https://www.diva-portal.org/smash/get/diva2:806023/FULLTEXT01.pdf,

Gormally, C. Brickman, P. \& Lutz, M. 2012. Developing a test of scientific literacy skills (TOSLS): Measuring undergraduates' evaluation of scientific information and arguments. CBE-Life Sciences Education Vol. 11.

Herlanti, Rustaman, Rohman \& Fitriani. (2012). Kualitas argumentasi pada diskusi isu sosiosaintifik mikrobiologi melalui weblog. Jurnal Pendidikan IPA Indonesia 1(2). 168-177.

Kementerian Pendidikan dan Kebudayaan. 2017. Konsep literasi sains dalam Kurikulum 2013. Pusat Kurikulum dan Perbukuan Jakarta.

Mulyadi, M. (2011). Penelitian Kuantitatif dan Kualitatif serta Pemikiran Dasar Menggabungkannya. Jurnal Studi Komunikasi dan Media 15(1), 128-137. http://dx.doi.org/10.31445/jskm.2011.150106.

Novitasari, N. (2018). Profil Kemampuan Literasi Sains Mahasiswa Calon Guru Biologi. BIOSFER Jurnal Tadris Pendidikan Biologi 9(1), 36-44. https://doi.org/10.24042/biosf.vgi1.2877

Rahayu, S. (2015). Meningkatkan Profesionalisme Guru dalam Mewujudkan Literasi Sains Siswa Melalui Pembelajaran Kimia/IPA Berkonteks Isu-isu Sosiosaintifik (Socioscientific Issues). Keynote paper disampaikan dalam Seminar Nasional Pendidikan Kimia dan Sains Kimia di FPMIPA Universitas Negeri Cendana.

Odja, A. H. \& Payu, C. S. (2014). Analisis Kemampuan Awal Literasi Sains Siswa Pada Konsep IPA. Prosiding Seminar Nasional Kimia Jurusan Kimia FMIPA Universitas Negeri Surabaya.

Redhana, I W. (2015). Menyiapkan lulusan FMIPA yang menguasai keterampilan abad XXI. Prosiding Seminar Nasional FMIPA V Universitas Pendidikan Ganesha.

Salamah, P. N., Rusilowati, A. \& Sarwi. (2017). Pengembangan Alat Evaluasi Materi Tata Surya Untuk Mengukur Literasi Sains Siswa SMP. Unnes Physics Education Journal 6(3), 7-16. 
https://doi.org/10.15294/upej.v6i3.19308

Shofiyah, N. (2015). Deskripsi Literasi Sains Awal Mahasiswa Pendidikan IPA pada Konsep IPA. Jurnal Pedagogia 4(2), 113-120 http://doi.org/10.21070/pedagogia.v4i2.13

Turiman, P., Omar, J., Daud, M. A., Osman, K. (2012). Fostering the 21st Century skills through scientific literacy and science process skills. Procedia-Social and Behavioral sciences 59.

Zeidler, D., Nichols, B. H. (2009). Socioscientific Issues: Theory and Practice. Journal of Elementary Science Education 21(2). https://doi.org/10.1007/BF03173684

\section{Kompyang Selamet}

Dosen Program Studi S1 Pendidikan IPA FMIPA UNDIKSHA, aktif melakukan penelitian pada bidang Pendidikan IPA, dapat dihubungi melalui email: kompyangselamet@gmail.com

\section{Putri Sarini}

Mahasiswa Program Studi S1 Pendidikan IPA FMIPA UNDIKSHA, aktif melakukan penelitian pada bidang Pendidikan IPA, dapat dihubungi melalui email: putri.sarini@undiksha.ac.id

\section{Nyoman Suardana}

Dosen Program Studi Pendidikan S1 IPA FMIPA UNDIKSHA, aktif melakukan penelitian pada bidang Pendidikan IPA, dapat dihubungi melalui email: inyomansuardana@gmail.com 